\title{
Abundance and Distribution of Microplastics in the Water and Riverbank Sediment in Malaysia - A Review
}

\author{
Wei Sheng Choong ${ }^{1}$, Tony Hadibarata ${ }^{1, *(D)}$, Daniel Kuok Ho Tang 2 (D) \\ 1 Department of Environmental Engineering, Faculty of Engineering and Science, Curtin University Malaysia, CDT 250, \\ Miri, Malaysia \\ 2 Environmental Science Program, Division of Science and Technology, BNU-HKBU UIC, 2000 Jintong Road, Tangjiawan, \\ Zhuhai, GD 519087, China \\ * Correspondence: hadibarata@ curtin.edu.my;
}

Scopus Author ID 16233109100

Received: 14.10.2020; Revised: 10.12.2020; Accepted: 14.12.2020; Published: 16.12.2020

\begin{abstract}
One of the major global environmental issues often discussed and brought up by many governments in the world today is microplastic pollution. Microplastic pollution causes severe harm to biodiversity, especially aquatic organisms. In Malaysia, an estimate of 0.94 million tons of mishandled plastic wastes is generated daily. A total of 0.14 to 0.37 million tons of these plastic wastes are washed into the oceans, causing severe pollution to the aquatic life. Notable effects of microplastic pollution towards the aquatic organisms are deterioration of health, blockage of the digestive tract, the intoxication of the aquatic organisms, etc. Hence, this review will discuss the microplastic sources and prevalence, fate, and transport of microplastics, methods to access microplastics, and the impacts of microplastics. Given that research regarding the area of microplastics is still scarce in Malaysia this review will help to give some insight regarding the current situation and issue of microplastic pollution globally and in Malaysia. The review mainly focuses on microplastic abundance and distribution within the freshwater system and the sediments within it.
\end{abstract}

Keywords: microplastic; wastewaters; Malaysia; aquatic environment.

(C) 2020 by the authors. This article is an open-access article distributed under the terms and conditions of the Creative Commons Attribution (CC BY) license (https://creativecommons.org/licenses/by/4.0/).

\section{Introduction}

The current period and time in human history can be acknowledged as the Plastic Age. Plastic is widely used today due to its merit of versatility that is durable, strong, inexpensive, corrosion-resistant, and lightweight, which has inversely resulted in the swift disposal and vigorous utilization of plastic products resulting in global plastic pollution [1,2]. Plastics are normally created by long chains of polymeric molecules that are constructed from inorganic and organic substances similar to hydrogen, oxygen, silicon, carbon, and chloride that can be normally acquired from natural gas, oil, and coal [3,4]. Many products in our daily life are made up of plastic, and with the steady rise of the global human population, the usage and consumption of plastic products will also continue to increase. An estimate of 8 million tons of plastic waste is discarded within the ocean annually, and experts believe that these plastic wastes will double by the year 2030 [5]. The marine environment is contaminated with large plastic debris and garbage and microplastics, which are produced from primary and secondary sources, which severely threatens the well-being and preservation of the aquatic environment [6]. In accordance with the National Oceanic and Atmospheric Administration, microplastics are plastic fragments tinier than $5 \mathrm{~mm}$ in size [7]. Primary microplastic sources are mainly 
generated from personal care and cosmetic products, whereas secondary sources of microplastic comprise further disintegration and breakdown of big plastic debris and garbage. The big plastic debris undertakes various degradation processes and fragmentation by UV solar radiation to breakdown. It forms smaller tiny pieces of plastic fragments within the aquatic environment [8]. There are speculations on whether how much of this plastic debris will wind up in the oceans and rivers where the plastic debris will undergo fragmentation and degradation $[9,10]$. Microplastic debris migrates, accumulates, and proliferates within the natural habitat, especially within the aquatic environment from the flowing rivers to the ocean surface and within the ocean's seabed [11]. Microplastic pollution can be considered omnipresent and persistent in the entire global oceans and is a severe threat to marine ecosystems [12]. With the increasing concern and impacts of microplastic pollutions on the ecosystem and human health, this study will provide further insight as well as baseline data for future microplastic pollution studies, especially on the abundance and distribution of microplastics within the freshwater system and riverbank sediments, which has received fewer attention juxtaposed to those of the marine environment.

\section{Situation and Condition of Microplastics Globally and in Malaysia}

The substantial distribution and accumulation of microplastics worldwide have recently received more attention and concerns regarding the relationship and potential impacts on aquatic life, agriculture, and human health [13,14,15]. Even though the microplastics' ecotoxicological impacts are still relatively unspecified, the environmental concern regarding microplastics is still very alarming for governments worldwide. For example, many studies and researches regarding toxicity studies done on microplastic in invertebrates mainly observed that adverse effects such as reduced feeding and energy reserve, physical harm to the digestive system, malnutrition, and incorporation of microplastics into the body tissue $[16,17,18,19]$. Another study displayed that the ingestion of microplastics happens throughout the entire food chain. The microplastics can shift from one trophic level to a higher one via zooplankton [20]. According to another two sampling studies, both observed that microplastics within fish and bivalves utilized for human consumption could also enter the human system via trophic transfer effect $[21,22]$. Hence, microplastics present within the aquatic environment can intoxicate the fishes and zooplankton, impacting human health, and other organisms that ingest them.

Malaysia, which is considered one of the four mega-diversity countries within the tropical ASEAN region besides the Philippines, Indonesia, and Singapore, produces an enormous $0.5-1.9 \mathrm{~kg} / \mathrm{capita} /$ day of municipal solid wastes (MSW), with plastic wastes being the highest of the overall composition at an estimate 25\% [23]. Subsequently, Malaysia has been crowned as one of the top plastic generators among the ASEAN countries [24]. However, environmental studies and data related to the abundance and distribution of plastic and microplastic pollution in the marine environment are deficient, especially in Asia's continent, as there are very few studies done on the contamination of microplastic within Asia. Studies regarding the contamination of microplastic are also very scarce in Malaysia, and the only available microplastic contamination studies are mostly from Peninsular Malaysia regarding coastal zones and beaches [24, 25, 26, 27]. In the case of East Malaysia, also known as Malaysian Borneo consisting of the Sarawak and Sabah states, only one study regarding the abundance of microplastics on beaches was done in the town of Kuching, Sarawak [28]. Besides the study stated above, almost no studies have been conducted on the abundance and distribution of microplastics in the rivers within East Malaysia. Most of the river studies 
conducted in either the Rejang, Miri, or Baram river are mainly done on heavy metal tracing or evaluation of decadal shoreline changes and none on microplastic pollution [29, 30, 31]. In Peninsular Malaysia, most of the microplastic studies also mainly focus on the coastal and beach areas. None of the microplastic studies were undertaken in the rivers or the freshwater systems in Malaysia except for a study by Sarijan, which conducted a microplastic sediment test in the Skudai and Terbau Rivers in Johor [32].

\section{Microplastic Sources and Prevalence}

In this modern and polluted era, microplastic contamination has been one of the top environmental concerns by governments worldwide. Since the early years of the $20^{\text {th }}$ century, only have these microplastic bits, fragments, granules, and fibers of different shapes and size, collectively dubbed as "microplastic", have been categorized as a potentially harmful pollutant $[33,34]$. As the first study of microplastics began in the year 1972 [35], microplastic fragments and granules can be found and documented in almost every surface water of every major ocean [36]. Normally, plastics that are meant to be produced in microscopic sizes, such as microbeads in facial cleansers, are defined as primary microplastics, while secondary microplastics are referred to as minuscule plastics particles acquired from the disintegration and breakdown of huge plastic debris [32]. According to some studies, it has stated that microplastic particles that are entering the freshwater system are primarily coming from secondary microplastics such as tires, synthetic clothing fibers, and single-use packaging [37, 38]. In addition, direct dumping of municipal solid wastes and agricultural runoffs are also some of the other factors in which microplastics have breached into the freshwater system [39]. Another study also displayed that effluent discharges from wastewater and sewage treatment plants are also potential notable point sources of microplastic contamination within the freshwater system [6]. As the integration of microplastic scrubbers within cosmetic products began from the early 1980s, the utilization of exfoliating cleansers integrating plastics has increased sharply [40]. This has resulted in many conventionally used natural cosmetic ingredients such as groundnuts and oatmeal to be replaced with these microplastic scrubbers [41]. Below in Figure 1 displays a synopsis regarding the major sources of microplastics within the freshwater environment.
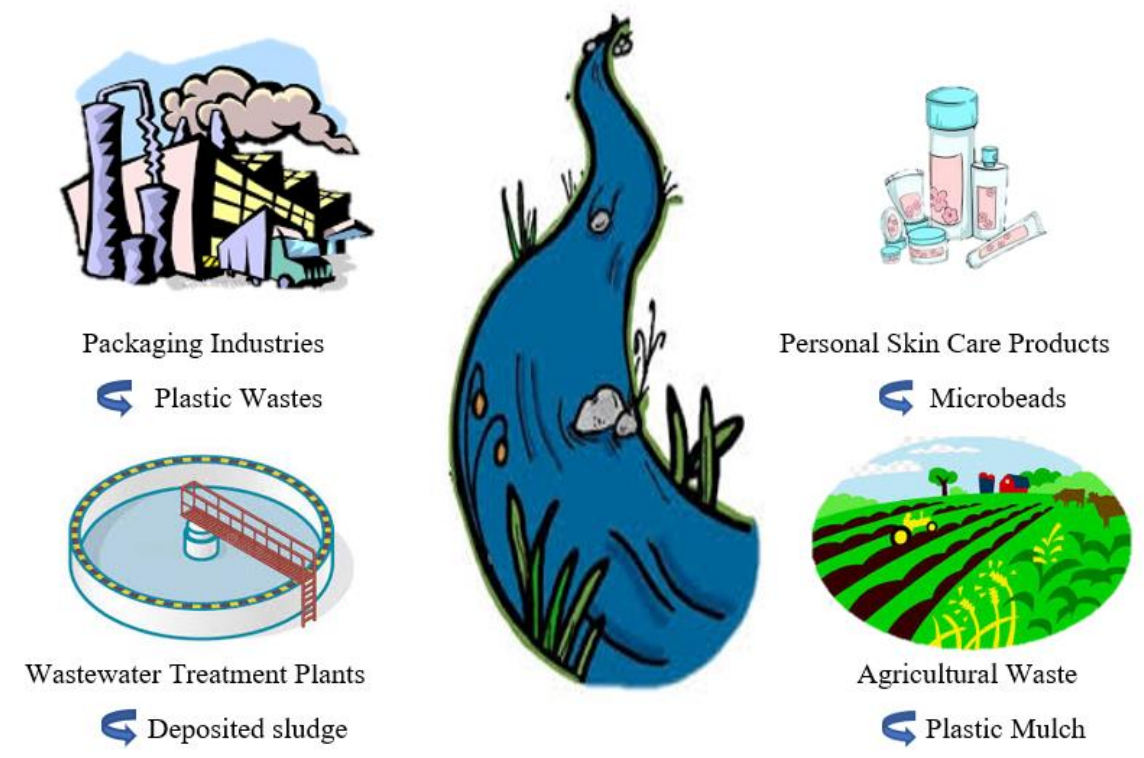

Figure 1. Key sources of microplastic contamination within freshwater environments. 
Table 1. Microplastic contamination studies were conducted in Malaysia.

\begin{tabular}{|c|c|c|c|c|c|c|}
\hline Location & Sample & $\begin{array}{l}\text { Sampling } \\
\text { Technique }\end{array}$ & Characterization & Targeted size & Abundance & Reference \\
\hline $\begin{array}{l}\text { Setiu Wetlands, } \\
\text { Terengganu }\end{array}$ & $\begin{array}{l}\text { Biological } \\
\text { sampling } \\
\text { (Fish) }\end{array}$ & Drift net & $\begin{array}{c}\text { ATR-FTIR } \\
\text { spectroscopy and } \\
\text { stereoscopic } \\
\text { microscope } \\
\end{array}$ & $\begin{array}{c}0.0043- \\
0.0157 \mathrm{~mm}\end{array}$ & $\begin{array}{c}\text { Range: } \\
1260-1961 \\
\text { particles per fish }\end{array}$ & [42] \\
\hline $\begin{array}{l}\text { Skudai River, } \\
\text { Johor }\end{array}$ & Sediment & $\begin{array}{c}\text { Sediment } \\
\text { collection using } \\
\text { a box corer } \\
\text { (Wildco) }\end{array}$ & $\begin{array}{c}\text { (HSZ-600) Microscope } \\
\text { with } 40 \times-45 \times \\
\text { magnification }\end{array}$ & $<5 \mathrm{~mm}$ & $\begin{array}{l}\text { Mean: } 200 \pm 80 \\
\text { particles per kg }\end{array}$ & [32] \\
\hline $\begin{array}{l}\text { Terbau River, } \\
\text { Johor }\end{array}$ & Sediment & $\begin{array}{c}\text { Sediment } \\
\text { collection using } \\
\text { a box corer } \\
\text { (Wildco) }\end{array}$ & $\begin{array}{c}\text { (HSZ-600) Microscope } \\
\text { with } 40 \times-45 \times \\
\text { magnification }\end{array}$ & $<5 \mathrm{~mm}$ & $\begin{array}{c}\text { Mean: } \\
680 \pm 140 \\
\text { particles per kg }\end{array}$ & [32] \\
\hline $\begin{array}{l}\text { Kuala Nerus } \\
\text { Beach, } \\
\text { Terengganu }\end{array}$ & Surface water & $\begin{array}{c}\text { 5.7L calibrated } \\
\text { steel sampler } \\
\text { and } 20 \mu \mathrm{m} \\
\text { serial filtration } \\
\text { net } \\
\end{array}$ & $\begin{array}{c}\text { Stereoscopic } \\
\text { microscope at } 50 \times \\
\text { magnification and FTIR } \\
\text { spectroscopy }\end{array}$ & $<5 \mathrm{~mm}$ & $\begin{array}{c}\text { Range: } \\
0.13-0.69 \\
\text { particles per kg }\end{array}$ & [26] \\
\hline $\begin{array}{ll}\text { Kuantan } & \text { Port, } \\
\text { Pahang } & \end{array}$ & Surface water & $\begin{array}{c}\text { 5.7L calibrated } \\
\text { steel sampler } \\
\text { and } 20 \mu \mathrm{m} \\
\text { serial filtration } \\
\text { net }\end{array}$ & $\begin{array}{c}\text { Stereoscopic } \\
\text { microscope at } 50 \times \\
\text { magnification and FTIR } \\
\text { spectroscopy }\end{array}$ & $<5 \mathrm{~mm}$ & $\begin{array}{c}\text { Range: } \\
0.14-0.15 \\
\text { particles per } \mathrm{kg}\end{array}$ & [26] \\
\hline $\begin{array}{l}\text { Santubong } \\
\text { Beach, Kuching }\end{array}$ & Sediment & $\begin{array}{c}\text { Scoop } \\
\text { sediments until } \\
\text { a depth of } 2 \mathrm{~cm} \\
\text { using stainless } \\
\text { steel spoon and } \\
\text { sieved through } 1 \\
\text { mm mesh }\end{array}$ & $\begin{array}{c}\text { Carl Zeiss Scanning } \\
\text { Electron Microscope } \\
\text { and FTIR spectroscopy }\end{array}$ & $>15 \mathrm{~mm}$ & $\begin{array}{c}\text { Mean: } \\
0.0358 \pm 0.062 \\
\text { particles per } g\end{array}$ & [28] \\
\hline $\begin{array}{l}\text { Trombol Beach, } \\
\text { Kuching }\end{array}$ & Sediment & $\begin{array}{c}\text { Scoop } \\
\text { sediments until } \\
\text { a depth of } 2 \mathrm{~cm} \\
\text { using stainless } \\
\text { steel spoon and } \\
\text { sieved through } 1 \\
\text { mm mesh }\end{array}$ & $\begin{array}{l}\text { Carl Zeiss Scanning } \\
\text { Electron Microscope } \\
\text { and ATR-FTIR } \\
\text { spectroscopy }\end{array}$ & $>15 \mathrm{~mm}$ & $\begin{array}{c}\text { Mean: } \\
1.7343 \pm 2.173 \\
\text { particles per g }\end{array}$ & [28] \\
\hline
\end{tabular}

In Malaysia, researchers have found that the contribution of microplastics within the river and marine water systems is to be a mix of both primary and secondary microplastic sources [28, 43, 44]. Table 1 shows the studies available regarding the microplastic contamination in freshwater and marine environments of Malaysia. However, some researches on the Malaysian rivers have found more fragments and fibers of microplastic formed through UV degradation of plastic debris rather than small round pellets from facial products [24, 28]. Given that Malaysia is one of the few ASEAN countries with one of the highest MSW generated annually, the chances of mismanaged plastic debris that infiltrate the river and marine water systems are extremely likely. Hence, huge amounts of plastic debris may be present within the Malaysian rivers [45]. This plastic debris is exposed to sunlight over prolonged periods. This can cause photo-degradation as the UV radiation present within sunlight causes the polymer-matrix within the plastic molecule to oxidize, causing bondcleavage $[9,46]$. This degradation process may cause additives, depicted to strengthen the durability and resistance to plastic corrosion, to wear out, resulting in the plastic losing structural integrity and becoming highly susceptible to fragmentation caused by waveturbulence and abrasion [47, 48]. Hence, plastic waste mismanagement can be regarded as one of the key anthropogenic factors impacting the presence, abundance, and distribution of microplastics within the freshwater and marine environments. 


\section{Fate and Transport of Microplastics}

Table 2 shows the data regarding the most common plastic polymer types and their density. Estimating and anticipating the fate of microplastics within the aquatic ecosystem is quite problematic as microplastics' properties vary from one to another. Microplastics are not just one element with the same property, but microplastics come in plenty of variances, shapes, and sizes and have distinct properties that can change and disrupt the properties and behaviors of their surrounding environment. Usually, manufacturers frequently add different chemicals to modify and obtain different properties and quality of plastic, which causes plastic produced by different producers to have their perceptible characteristics and properties. For example, microplastics will reside in different parts of the water column with relevance to their density when disposed of within the marine environment [49].

Given that the density of plastic is lower than the density of freshwater $(\rho=1000$ $\mathrm{kg} / \mathrm{m}^{3}$ ), the microplastics will stay afloat as a result of positive buoyancy. They will be shifting according to the regulation of the current water flow. Several other microplastic characteristics that influence their etiquette also include biodegradability, oxidation resistance, surface properties, and partial crystallinity [50].

Table 2. Data regarding the most common plastic polymer types and their density.

\begin{tabular}{|c|c|c|c|c|}
\hline Polymer & Abbreviation & $\begin{array}{l}\text { Min. Density } \\
\left(\mathrm{g} / \mathrm{cm}^{3}\right)\end{array}$ & $\begin{array}{l}\text { Max. Density } \\
\left(\mathrm{g} / \mathrm{cm}^{3}\right)\end{array}$ & Main Application \\
\hline Polyethylene & $\mathrm{PE}$ & 0.91 & 0.97 & Packaging \\
\hline Polyester & PES & 1.24 & 2.3 & Textiles \\
\hline $\begin{array}{l}\text { Polyethylene } \\
\text { terephthalate }\end{array}$ & PET & 1.37 & 1.45 & Packaging \\
\hline Polystyrene & PS & 1.01 & 1.04 & Packaging \\
\hline Expanded polystyrene & EPS & 0.016 & 0.640 & $\begin{array}{l}\text { Food packaging, construction } \\
\text { material }\end{array}$ \\
\hline Ethylene vinyl acetate & EVA & 0.92 & 0.94 & Others \\
\hline Alkyd & $\mathrm{Al}$ & 1.67 & 2.1 & Paints, fibers \\
\hline Polyvinyl chloride & $\mathrm{PVC}$ & 1.16 & 1.58 & Building and construction \\
\hline $\begin{array}{l}\text { Polymethyl } \\
\text { methacrylate }\end{array}$ & PMMA & 1.17 & 1.2 & Electronics (touch screens) \\
\hline Polyamide (nylon) & PA & 1.02 & 1.05 & Automotive, textiles \\
\hline Polyacrylonitrile & PAN & 1.09 & 1.2 & Textiles \\
\hline Polyvinyl alcohol & $\mathrm{PVOH}$ & 1.19 & 1.31 & Textiles \\
\hline $\begin{array}{l}\text { Acrylonitrile } \\
\text { butadiene styrene }\end{array}$ & ABS & 1.06 & 1.08 & Electronics \\
\hline Polyurethane & PUR & 0.03 & 0.1 & Building and construction \\
\hline
\end{tabular}

Distinct types of freshwater systems also have contrasting inferences on the fate and transport of microplastics. For example, in estuaries, where the saline water and freshwater connect, the combined impact of salinity and wave turbulence can interchange with microplastic density, charge, and size [51]. This will cause larger flocs and, overall, a much higher microplastic deposition within the estuaries. Thus, the likelihood that the microplastics would eventually be transported to the marine environment as the rivers are connected to the ocean is highly plausible [52]. Microplastics in static or isolated water bodies would be maintained and stockpiled within the water bodies acting like a sink [51]. Microplastics' transportation is also significantly impacted by the hydrological attributes of the freshwater systems, which include the physical characteristics of the water body such as water depth, topography, water flow velocity, and seasonal differences of water flow [53]. For example, high flow conditions can cause the displacement of previously sedimented microplastics and subsequently discharge the water body's microplastics to the surrounding aquatic environments. In contrast, low flow conditions will lead to an increased accumulation of 
microplastics [54]. In Malaysia, there are only two seasons: the dry season and rainy season; hence, the transportation of microplastics within the Malaysian rivers significantly depends on the season, which will affect the river flow rates and affect the fate and transportation of microplastics [55].

\section{Assessing Microplastic Abundance}

Plastic has been widely referred to by scientists globally as the key component of marine debris, a classification which comprises of both anthropogenic litter (e.g., wood, metal, glass) and occurring natural flotsam (e.g., vegetation and pumice) [46]. Nevertheless, microplastics are considered as an extensively under-researched element of aquatic debris because it is very troublesome to determine the abundance, distribution, density, and types of this contaminant within the aquatic ecosystem [56]. In accordance with a study, it has stated that the quantification of plastic debris that is already present within the aquatic ecosystem is intricated by the expanse of the oceans and rivers juxtaposed to the size of the plastic debris being evaluated [6]. This issue is further complicated by the spatial and temporal variability owing to the water currents and weather patterns [57]. Nonetheless, developed sampling techniques such as beachcombing, water sampling, sediment sampling, and biological sampling can be conducted to identify microplastics' presence within the marine environment [46]. In this literature review, the water sampling technique and sediment sampling technique will be more focused on as it is more linked to the topic's objective.

\subsection{Water sampling.}

The primary technique for collecting water samples either in the river or coastal waters is by implementing a trawl along the intersection using fine meshes or utilizing a neuston net to drag through the water [58]. The neuston net is originally utilized to capture planktons. However, microplastic water sampling enables large volumes of water to be sampled without fuss. Many literature and studies have utilized different mesh sizes of nets, ranging from $200-$ $300 \mu \mathrm{m}[32,59,60]$. Utilizing a mesh of $300 \mu \mathrm{m}$ or less will significantly increase the number of microplastics collected. However, the entrapment of biological biomass will also increase [61]. Literature has also displayed that water sampling is to be conducted at the surface, subsurface, and along the benthos of the water [36, 62]. In the study of Desforges et al., 2014, the study collected water samples and filtered the large plastic debris utilizing a coarse $5 \mathrm{~mm}$ filter to remove large debris and biomass, then followed by $250 \mu \mathrm{m}$ and $125 \mu \mathrm{m}$ aperture size to filter the microplastics [63]. There is a potential for a loss of microplastics. However, the recovery of microplastics at each filtration mesh is still relatively unknown. However, the study of Lusher et al., 2014, the study demonstrated that through the stacking of the mesh filters of the same size repetitively, the single mesh sieve was not effective at extracting the microplastics from the water [64]. Thus, the results propose that there is an undervaluation of microplastic abundance across samples collected. Most of the microplastic studies did not utilize any preservation method or state that the microplastic samples were immediately processed after collection $[58,64,65]$. This is quite acceptable for water samples, especially for microplastics, as they do not require to be chemically preserved.

One of the critical aspects of water sampling in microplastic research is the severance of microplastics within the biomass. Major microplastic studies have all implemented the flotation separation method to extract microplastic from water samples, either standalone or 
mixed with a hypersaline solution $[58,62]$. The most widely implemented one is the hypersaline solution with sodium chloride, the common solution used within the density separation process [6]. The water sample is mixed with the sodium chloride solution and agitated for a few minutes by stirring before leaving overnight for the separation process [66]. In Dubaish \& Liebezeit, 2013, the study utilized two-part digestion beginning with 30\% hydrogen peroxide and treatment with $40 \%$ hydrofluoric acid directly after [67]. Even though chemical digestion is very potent in reducing organic matter, the microplastics may be susceptible to acids. Another study, however, showed that through visual inspection, the organic matters within the water samples collected were digested with hydrochloric acid while leaving the microplastics uncompromised [68]. This may be true through visual inspections, but the study did not demonstrate whether or not the microplastics' chemical characteristics were compromised. Hence, it is unfair to directly juxtapose and assess the recovery rates given that the microplastic identification techniques vary from each study. Table 3 shows the separation, sampling, and characterization techniques implemented to obtain and characterize microplastics in the river and marine environments globally.

Table 3. Water sampling techniques are implemented worldwide to identify microplastics.

\begin{tabular}{l|c|c|c|c|c|c|c}
$\begin{array}{l}\text { Sampling } \\
\text { method }\end{array}$ & $\begin{array}{c}\text { Mesh size } \\
(\boldsymbol{\mu m})\end{array}$ & $\begin{array}{c}\text { Sampling } \\
\mathbf{d e p t h}(\mathbf{m})\end{array}$ & $\begin{array}{c}\text { Separation } \\
\text { methods }\end{array}$ & Separation chemicals & $\begin{array}{c}\text { Characterizati } \\
\text { on methods }\end{array}$ & Location & Reference \\
\hline $\begin{array}{l}\text { Continuous } \\
\text { intake }\end{array}$ & 1 & 5 & Visual & Manual & FTIR & Antarctica & {$[69]$} \\
\hline Sieves & 20 & Surface & $\begin{array}{c}\text { Flotation and } \\
\text { visual }\end{array}$ & $\begin{array}{c}\text { Milli-Q water, filtered } \\
\text { by using GF/F 0.7 } \mu \mathrm{m} \\
47 \mathrm{~mm}\end{array}$ & FTIR & Malaysia & [26] \\
\hline Neuston net & 300 & Surface & $\begin{array}{c}\text { Floatation and } \\
\text { visual }\end{array}$ & NaCl & FTIR & Portugal & [70] \\
\hline Manta trawl & 333 & 0.05 & Visual & Manual & FTIR & Europe & {$[71]$} \\
\hline Sieves & 12 & $\begin{array}{c}\text { Not } \\
\text { determine } \\
\mathrm{d}\end{array}$ & $\begin{array}{c}\text { Density } \\
\text { flotation and } \\
\text { oxidant }\end{array}$ & $\mathrm{ZnCl}$ and $30 \% \mathrm{H}_{2} \mathrm{O}_{2}$ & TGA-DSC & Germany & {$[72]$}
\end{tabular}

\subsection{Sediment sampling.}

Analyzing sediment samples to determine the existence of microplastics started approximately 15 years ago and with even more regularly in the past few years. The sediment sampling method has the potential to identify microplastic presence from benthic materials collected from beaches, estuaries, and the seabed [73]. According to various studies, there are several sediment sampling types, which include deep-sea sand, beach sand, river sand, municipal soil, and mangrove mud, with the maximum depth of sampling varying from a range of $2-5 \mathrm{~cm}$ based on the sampling types conducted [71, 74, 75]. In order to separate any microplastics from the benthic material, saline water, or mineral salts, the water density within the sediment samples can be increased to allow the lower-density microplastics to be extracted through flotation. Simultaneously, larger plastic fragments visible by the naked eye can be removed using steel forceps under a light microscope [6]. With reference to various studies, the density flotation method normally utilizes sodium chloride or sodium iodide regardless of the depth of sampling or sediment type as the studies suspend the sediments within hypersaline sodium chloride solution after which the mixtures were permitted to settle overnight $[71,73,76]$. Another study, however, suggested an alternative technique for characterizing the microplastics from sediment samples via staining the samples with a Nile Red (NR) acetone solution [70]. While the method displayed improvement at enhancing the speed for visual monitoring and promises general particle categorization, the N-R stained microplastic particles 
rely on utilizing small amounts or concentration of suspension and necessitate the adaptation of FTIR imaging optics [70]. In the case of the river and marine water samples, FTIR was the characterization technique of choice in sediment samples, selected in over $50-60 \%$ of the articles and journals reviewed $[6,47,77]$. Other techniques, such as chemical characterization by Raman spectroscopy or physical characteristics, characterize the microplastics [37]. Table 4 shows the separation, sampling, and characterization techniques implemented to obtain and characterize microplastics in the river and marine sediments globally.

Table 4. Sediment sampling techniques were implemented worldwide to identify microplastics.

\begin{tabular}{|c|c|c|c|c|c|c|}
\hline Depth $(\mathrm{cm})$ & Sediment & $\begin{array}{c}\text { Separation } \\
\text { method }\end{array}$ & $\begin{array}{c}\text { Separation } \\
\text { chemicals }\end{array}$ & $\begin{array}{c}\text { Characterization } \\
\text { methods }\end{array}$ & Location & Reference \\
\hline 10 & River & $\begin{array}{l}\text { Density } \\
\text { flotation }\end{array}$ & $\mathrm{ZnCl}_{2}$ & Raman & UK & [37] \\
\hline $\begin{array}{l}\text { Not } \\
\text { determined }\end{array}$ & River & $\begin{array}{l}\text { Density } \\
\text { flotation }\end{array}$ & $\mathrm{NaCl}$ & $\begin{array}{c}\text { Physical } \\
\text { characteristics }\end{array}$ & Malaysia & {$[32]$} \\
\hline 2 & Beach & $\begin{array}{l}\text { Density } \\
\text { flotation }\end{array}$ & $\mathrm{NaCl}$ & FTIR & Portugal & [71] \\
\hline $\begin{array}{l}\text { Sediment } \\
\text { cores }\end{array}$ & Deep-sea & $\begin{array}{c}\text { Density } \\
\text { flotation }\end{array}$ & $\mathrm{NaI}$ & Raman & $\begin{array}{c}\text { Atlantic \& } \\
\text { Midland }\end{array}$ & [77] \\
\hline 5 & Beach & $\begin{array}{l}\text { Oil extraction } \\
\text { protocol }\end{array}$ & $\begin{array}{c}\text { Canola oil, } \mathrm{NaI} \\
\text { and } \mathrm{CaCl}_{2}\end{array}$ & FTIR & Canada & [78] \\
\hline
\end{tabular}

\section{Impacts of Microplastics}

The impacts of microplastics on the freshwater and marine system have raised many concerns worldwide. The impacts of microplastics on the aquatic ecosystem have been analyzed in various articles [5,25,79,80]. The aquatic organism's reported effects include obstruction of the digestive tract, mortality, malnutrition, inflammatory response, behavior changes, lower energy reserves, disruption in the reproductive system, and formation of ulcers. The effects stated are influenced by the microplastics' distinctive features, such as their shape, size, and properties. However, the studies have also noted that microplastics' negative impacts are required at a much higher dose than those observed in the environmental sample. There could be a possibility whereby the prolonged period of exposure towards a microplastic environment may adversely affect the aquatic organisms, but that is still relatively unknown.

According to Wong et al., 2020, the study showed that microplastics are also abundantly present within other terrestrial ecosystems [79]. According to a cross-sectional monitoring study, it was observed in the experiment that $30 \%$ of the 230 goats and nearly half of the 185 sheep population had plastic debris within their digestive tract [81]. This is very alarming as not only aquatic organisms are directly affected by the microplastic contamination, but terrestrial organisms as well. Like the microplastics in the aquatic system, the terrestrial microplastics can be shifted within the food chains and, eventually, the food webs as well [82]. Researchers nowadays are greatly concerned about microplastics' present ecotoxicology studies and suggested a call for boosting the consistency and applicability of environmental research regarding microplastics for better in-depth understanding in the future [54,83,84].

Apart from having biological impacts on individual organisms, microplastics also cause ecological impacts. According to a study, microplastics under high concentrations were able to affect the soil biophysical environment as geochemical cycles within the soil systems were modified due to the leaching additives of the microplastics present [85]. The cross-reference study from Lwanga et al., 2016 asserted that microplastics' dosages above 50\% by weight within the topsoil are considered to be environmentally disruptive as microplastics are nonbiodegradable in the soil as a result of low oxidization and exposure to UV [82]. In addition, 
the omnipresence of microplastics within the soil system may also have the potential to impact the behavior, growth, and reproduction of soil fauna, such as the earthworm. With reference to a study, the study had found that the springtails and earthworms found abundantly within the soil were able to act as a host for the microplastic and transport the microplastic within the soil system [86]. Not only that, another study has shown that while microplastics were present within the earthworms, the microplastics damages the earthworms via disrupting the gut microbiomes within, causing a significant decline in the earthworms' reproduction and growth rate [87]. Study areas regarding the ecological impacts of microplastics are still very scarce and limited. Thus, more research is in this area is required to fully acknowledge the extent of the impacts happening within the soil system.

\section{Conclusion}

Identified as a contaminant of rising threat to the environmental ecosystem, microplastics have already been dispersed to numerous environmental media and requires immediate attention. Microplastics pollution in the environmental ecosystem is projected to increase constantly, given the increase in global production and plastics application. Evidence proposes that the river and marine ecosystems of Malaysia to be contaminated with microplastics particles. However, the current microplastics research conducted within the Malaysian rivers is still inefficient to clearly determine the actual severity of microplastics pollutions and sources within the country, but it provides many future research insights. Various research gaps are still present in microplastics analysis, including the impacts of microplastics on human health, aquatic species and soil properties, the standardized sampling method of microplastics, the factors affecting the source and prevalence of microplastics, and the factors affecting microplastics degradation. Hence, further research and investigation in the areas stated above are crucial for the improvement and legitimacy of the field of microplastics contamination and analysis, which helps to allow a better understanding of the problems and formulate sustainable solutions to mitigate microplastic contamination.

\section{Funding}

This research received no external funding.

\section{Acknowledgments}

This research has no acknowledgment.

\section{Conflicts of Interest}

The authors declare no conflict of interest. The funders had no role in the study's design; in the collection, analyses, or interpretation of data; in the writing of the manuscript, or in the decision to publish the results.

\section{References}

1. Pan, Z.; Sun, Y.; Liu, Q.; Lin, C.; Sun, X.; He, Q.; Zhou, K.; Lin, H. Riverine microplastic pollution matters: a case study in the Zhangjiang River of Southeastern China. Marine Pollution, Bulletin 2020, 159, https://doi.org/10.1016/j.marpolbul.2020.111516. 
2. Ganesh, K.A.; Anjana, K.; Hinduja, M.; Sujitha, K.; Dharani, G. Review on plastic wastes in marine environment-biodegradation and biotechnological solutions. Marine Pollution, Bulletin 2020, 150, https://doi.org/10.1016/j.marpolbul.2019.110733.

3. Shah, A.A.; Hasan, F., Hameed, A.; Ahmed, S. Biological degradation of plastics: a comprehensive review. Biotechnology Advances 2008, 26, 246-265, https://doi.org/10.1016/j.biotechadv.2007.12.005.

4. Sanchez, C. Microbial capability for the degradation of chemical additives present in petroleum-based plastic products: a review on current status and perspectives. Journal of Hazardous Materials 2021, 402, https://doi.org/10.1016/j.jhazmat.2020.123534.

5. Zhang, C.; Wang, S.; Sun, D.; Pan, Z.; Zhou, A.; Xie, S.; Wang, J; Zou, J. Microplastic pollution in surface water from east coastal areas of Guangdong, South China and preliminary study on microplastics biomonitoring using two marine fish. Chemosphere 2020, 256, https://doi.org/10.1016/j.chemosphere.2020.127202.

6. Cole, M.; Lindeque, P.; Halsband, C.; Galloway, T.S. Microplastics as contaminants in the marine environment: a review. Marie Pollution Bulletin 2011, 62, 2588-2597, https://doi.org/10.1016/j.marpolbul.2011.09.025.

7. Garces-Ordonez, O.; Mejia-Esquivia, K. A.; Sierra-Labastidas, T.; Patino, A.; Blandon, L.M.; Diaz, L.F.E. Prevalence of microplastic contamination in the digestive tract of fishes from mangrove ecosystem in Cispata, Colombian Caribbean. Marine Pollution Bulletin 2020, 154, https://doi.org/10.1016/j.marpolbul.2020.111085.

8. Ivar Do Sul, J.A; Costa, M.F. The present and future of microplastic pollution in the marine environment. Environment Pollution 2014, 185, 352-364, https://doi.org/10.1016/j.envpol.2013.10.036.

9. Andrady, A.L. Microplastics in the marine environment. Marine Pollution Bulletin 2011, 62, 1596-1605, https://doi.org/10.1016/j.marpolbul.2011.05.030.

10. Thushari, G.G.N.; Senevirathna, J.D.M. Plastic pollution in the marine environment. Heliyon 2020, 6, https://doi.org/10.1016/j.heliyon.2020.e04709.

11. Moore, C.J. Synthetic polymers in the marine environment: a rapidly increasing, long-term threat. Environmental Research 2008, 108, 131-139, https://doi.org/10.1016/j.envres.2008.07.025.

12. Pirashab, M.; Hossini, H.; Makhdoumi, P. Review of microplastic occurrence and toxicological effects in marine environment: experimental evidence of inflammation. Process Safety and Environmental Protection 2020, 142, 1-14, https://doi.org/10.1016/j.psep.2020.05.050.

13. Oliveria, M.; Ribeiro, A.; Hylland, K.; Guilhermino, L. Single and combined effects of microplastics and pyrene on juveniles (0+ group) of the common goby Pomatoschistus microps (Teleostei, Gobiidae). Ecological Indicators 2013, 34, 641-647, https://doi.org/10.1016/j.ecolind.2013.06.019.

14. Llorca, M.; Alvarez-Munoz, D.; Abalos, M.; Rodriguez-Mozaz, S.; Santos, L.H.M.L.M.; Leon, V.M.; Campillo, J.A.; Martinez-Gomez, C.; Abad, E.; Farre, M. Microplastics in Mediterranean coastal area: toxicity and impact for the environment and human health. Trends in Envrionmental Analytical Chemistry 2020, 27, https://doi.org/10.1016/j.teac.2020.e00090.

15. Tang, D.K.H. Effects of microplastics on agriculture: a mini-review. Asian Journal of Atmospheric Environment 2020, 13, 1-9, https://doi.org/10.9734/AJEE/2020/v13i130170.

16. Browne, M. A.; Crump, P.; Niven, S. J.; Tueten, E.; Tonkin, A.; Galloway, T.; Thompson, R. Accumulation of microplastic on shorelines woldwide: sources and sinks. Environmental Science Technology 2011, 45, 9175-9179, https://doi.org/10.1021/es201811s.

17. Cole, M.; Lindeque, P.; Fileman, E.; Halsband, C.; Galloway, T.S. The impact of polystyrene microplastics on feeding, function and fecundity in the marine copepod Calanushelgolandicus. Environmental Science Technology 2015, 49, 1130-1137, https://doi.org/10.1021/es504525u.

18. Yu, S.P.; Chan, B.K.K. Intergenerational microplastics impact the intertidal barnacle Amphibalanus amphitrite during the planktonic larval and benthic adult stages. Environmental Pollution 2020, 267, https://doi.org/10.1016/j.envpol.2020.115560.

19. Tang, D.K.H. Ecotoxicological impacts of micro and nanoplastics on marine fauna. Oceanography and Marine Biology 2020, 3, 1-5.

20. Setala, O.; Fleming-Lehtinen, V.; Lethinieni, M. Ingestion and transfer of microplastics in the planktonic food web. Environmental Pollution 2014, 185, 77-83, https://doi.org/10.1016/j.envpol.2013.10.013.

21. Van Cauwenberghe, L; Janssen, C.R. Microplastics in bivalves cultured for human consumption. Environmental Pollution 2014, 193, 65-70, https://doi.org/10.1016/j.envpol.2014.06.010.

22. Arauja, A.P.D.C.; Malafia, G. Microplastic ingestion induces behavioral disorders in mice: a preliminary study on the trophic transfer effects via tadpoles and fish. Journal of Hazardous Materials 2021, 401, https://doi.org/10.1016/j.jhazmat.2020.123263.

23. Aja, O.C.; Al-Kayiem, H.H. Review of municipal solid waste management options in Malaysia, with an emphasis on sustainable waste-to-energy options. Journal of Material Cycles and Waste Management 2014, 16, 693-710, https://doi.org/10.1007/s10163-013-0220-z.

24. Amin, R.M.; Sohaimi, E.S.; Anuar, S.T.; Bachok, Z. Microplastic ingestion by zooplankton in Terengganu coastal waters, southern South China Sea. Marine Pollution Bulletin 2020, 150, https://doi.org/10.1016/j.marpolbul.2019.110616. 
25. Auta, H.S.; Emenike, C.U.; Fauziah, S.H. Screening of Bacillus strains isolated from mangrove ecosystems in Peninsular Malaysia for microplastic degradation. Environmental Pollution 2017, 231, 1552-1559, https://doi.org/10.1016/j.envpol.2017.09.043.

26. Khalik, W.M.A.W.M.; Ibrahim, Y.S.; Anuar, S.T.; Govindasamy, S.; Baharuddin, N.F. Microplastics analysis in Malaysian marine waters: a field study of Kuala Nerus and Kuantan. Marine Pollution Bulletin 2018, 135, 451-457, https://doi.org/10.1016/j.marpolbul.2018.07.052.

27. Fauziah, S.H.; Liyana, I.A.; Agamuthu, P. Plastic debris in the coastal environment: the invincible threat? abundance of buried plastic debris on Malaysian beaches. Waste Management and Research 2015, 33, 812821, https://doi.org/10.1177/0734242X15588587.

28. Noik, V.J; Tuah, P.M. A first survey on the abundance of plastics fragments and particles on two sandy beaches in Kuching, Sarawak, Malaysia. Paper presented at the 9th Curtin University of Technology Science and Engineering International Conference Malaysia, 2014, https://doi.org/10.1088/1757-899X/78/1/012035.

29. Prabakaran, K.; Nagarajan, R.; Eswaramoorthi, S.; Anandkumar, A.; Franco, F.M. Environmental significance and geochemical speciation of trace elements in lower Baram River sediments. Chemosphere 2019, 219, 933-953, https://doi.org/10.1016/j.chemosphere.2018.11.158.

30. Sim, S.F.; Rajendran, M.; Nyanti. L.; Ling, T.Y.; Grinang, J.; Liew, J.J. Assessment of trace metals in water and sediment in a tropical river potentially affected by land use activities in northern Sarawak, Malaysia. International Journal of Environment Research 2017, 11, 99-110, https://doi.org/10.1007/s41742-0170011-9.

31. Nagajaran, R.; Jonathan, M.P.; Roy, P.D.; Wai-Hwa, L.; Prasanna, M.V.; Sarkar, S.K.; Navarrete-Lopez, M. Metal concentrations in sediments from tourist beaches of Miri City, Sarawak, Malaysia (Borneo Island). Marine Pollution Bulletin 2017, 73, 369-373, https://doi.org/10.1016/j.marpolbul.2013.05.036.

32. Sarijan, S.; Azman, S.; Said, M.I.M.; Andu, Y.; Zon, N.F. Microplastics in sediment from Skudai and Tebrau river, Malaysia: a preliminary study. Paper presented at the The $12^{\text {th }}$ International Civil Engineering Post Graduate Conference (SEPKA)-The $3^{\text {rd }}$ International Symposium on Expertise of Engineering Design (ISEED), Malaysia 2018, https://doi.org/10.1051/matecconf/201825006012.

33. Thompson, R.C.; Olsen, Y.; Mitchell, R.P.; Davis, A.; Rowland, S.J.; John, A.W.G.; McGonigle, D.; Russell, A.E. Lost at sea: where is all the plastic? Science 2014, 304.

34. Christensen, N.D.; Wisinger, C.E.; Maynard, L.A.; Chauhan, N.; Schubert, J.T.; Czuba, J.A.; Barone, J.R. Transport and characterization of microplastics in inland waterways. Journal of Water Process Engineering 2020, 38, https://doi.org/10.1016/j.jwpe.2020.101640.

35. Carpenter, E.J.; Anderson, S.J.; Harvey, G.R.; Miklas, H.P. Polystyrene Spherules in Coastal Waters. Science 1972, 178, 749-750, https://doi.org/10.1126/science.178.4062.749.

36. Cozar, A.; Echevarria, F.; Gonzalez-Gordillo, J.I.; Irigoien, X.; Ubeda, B.; Hernandez-Leon, S.; Palma, A.T.; Navarro, S.; Garcia-de-Lomas, J.; Ruiz, A.; Fernandes-de-Puelles, M.L.; Duarte, C.M. Plastic debris in the open ocean. Proceedings of the National Academy of Sciences of the United States of America 2014, 111, 10239-10244, https://doi.org/10.1073/pnas.1314705111.

37. Horton, A.A.; Svendsen, C.; Williams, R.J.; Spurgeon, D.J.; Lahive, E. Large microplastic particles in sediments of tributaries of the River Thames, UK-abundance, sources and methods for effective quantification. Marine Pollution Bulletin 2017, 114, 218-26, https://doi.org/10.1016/j.marpolbul.2016.09.004.

38. Khalid, N.; Aqeel, M.; Noman, A. Microplastics could be a threat to plants in terrestrial systems directly or indirectly. Environmental Pollution 2020, 267, https://doi.org/10.1016/j.envpol.2020.115653.

39. Free, C.M.; Jensen, O.P.; Mason, S.A.; Eriksen, M.; Williamson, N.J.; Boldgiv, B. High-levels of microplastic pollution in a large, remote, mountain lake. Marine Pollution Bulletin 2014, 85, 156-163, https://doi.org/10.1016/j.marpolbul.2014.06.001.

40. Fendall, L.S; Sewell, M.A. Contributing to marine pollution by washing your face: Microplastics in facial cleansers. Marine Pollution Bulletin 2009, 58, 1225-1228, https://doi.org/10.1016/j.marpolbul.2009.04.025.

41. Derraik, J.G.B. The pollution of the marine environment by plastic debris: a review. Marine Pollution Bulletin 2002, 44, 842-852, https://doi.org/10.1016/S0025-326X(02)00220-5.

42. Ibrahim, Y.S.; Rathman, R.; Anuar, S.T.; Khalik, W.M.A.W.M. Isolation and characterization of microplastic abundance in Lates calcarifer from Setiu Wetlands, Malaysia. Malaysian Journal of Analytical Science 2017, 21, 1054-1064, https://doi.org/10.17576/mjas-2017-2105-07.

43. Praveena, S.M.; Shaifuddin, S.N.M.; Akizuki, S. Exploration of microplastics from personal care and cosmetic products and its estimated emissions to marine environment: An evidence from Malaysia. Marine Pollution Bulletin 2018, 136, 135-140, https://doi.org/10.1016/j.marpolbul.2018.09.012.

44. Karbalaei, S.; Golieskardi, A.; Hamzah, H.B.; Abdulwahid, S.; Hanachi, P.; Walker, T.R.; Karami, A. Abundance and characteristics of microplastics in commercial marine fish from Malaysia. Marine Pollution Bulletin 2019, 148, 5-15, https://doi.org/10.1016/j.marpolbul.2019.07.072.

45. Jalil, M.A. Sustainable development in Malaysia: a case study on household waste management. Journal of Sustainable Development 2010, 3, 91-102. 
46. Barnes, D.K.A.; Galgani, F.; Thompson, R.C.; Morton, B. Accumulation and fragmentation of plastic debris in global environments. Philosophical Transactions of the Royal Society B 2009, 364, 1985-1998, https://doi.org/10.1098/rstb.2008.0205.

47. Browne, M.A.; Galloway, T.; Thompson, R. Microplastic-an emerging contaminant of potential concern? Integrated Environmental Assessment and Management 2007, 3, 559-561.

48. Moore, C.J. Synthetic polymers in the marine environment: a rapidly increasing, long-term threat. Environmental Research 2008, 108, 131-139, https://doi.org/10.1016/j.envres.2008.07.025.

49. Di, M.; Wang, J. Microplastics in surface waters and sediments of the Three Gorges Reservoir, China. Science of the Total Environment 2018, 616-617, 1620-1627, https://doi.org/10.1016/j.scitotenv.2017.10.150.

50. Andrady, A.L. The plastic in microplastics: a review. Marine Pollution Bulletin 2017, 119, 12-22, https://doi.org/10.1016/j.marpolbul.2017.01.082.

51. Eerkes-Medrano, D.; Thompson, R.C.; Aldridge, D.C. Microplastics in freshwater systems: a review of the emerging threats, identification of knowledge gaps and prioritisation of research needs. Water Research 2015, 75, 63-82, https://doi.org/10.1016/j.watres.2015.02.012.

52. Leslie, H.A.; Brandsma, S.H.; Van Velzen, M.J.M.; Vethaak, A.D. Microplastics en route: Field measurements in the Dutch river delta and Amsterdam canals, wastewater treatment plants, North Sea sediments and biota. Environment International 2017, 101, 133-142, https://doi.org/10.1016/j.envint.2017.01.018.

53. Lin, L.; Zuo, L.; Peng, J.; Cai, L.; Fok, L.; Yan, Y.; Li, H.; Xu, X. Occurrence and distribution of microplastics in an urban river: A case study in the Pearl River along Guangzhou City, China. Science of the Total Environment 2018, 644, 375-381, https://doi.org/10.1016/j.scitotenv.2018.06.327.

54. Zhang, K.; Shi, H.; Peng, J.; Wang, Y.; Xiong, X.; Wu, C.; Lam, P.K.S. Microplastic pollution in 'China's inland water systems: a review of findings, methods, characteristics, effects, and management. Science of the Total Environment 2018, 630, 1641-1653, https://doi.org/10.1016/j.scitotenv.2018.02.300.

55. Misha, S.; Abdullah, A.L.; Tamaldin, N.; Rosli, M.A.M.; Sachit, F.A. Simulation CFD and experimental investigation of PVT water system under natural Malaysian weather conditions. Energy Reports 2019, Advance online publication, https://doi.org/10.1016/j.egyr.2019.11.162.

56. Doyle, M.J.; Watson, W.; Bowlin, N.M.; Sheavly, S.B. Plastic particles in coastalpelagic ecosystems of the Northeast Pacific ocean. Marine Environmental Research 2011, 71, 41-52, https://doi.org/10.1016/j.marenvres.2010.10.001.

57. Ryan, P.G.; Moore, C.J.; Van Franeker, J.A.; Moloney, C.L. Monitoring the abundance of plastic debris in the marine environment. Philosophical Transactions of the Royal Society B: Biological Sciences 2009, 364, 1999-2012. https://doi.org/10.1098/rstb.2008.0207.

58. Hall, N.M.; Berry, K.L.E.; Rintoul, L.; Hoogenboom, M.O. Microplastic ingestion by scleractinian corals. Marine Biology 2015, 162, 725-732, http://dx.doi.org/10.1007/s00227-015-2619-7.

59. Guven, O.; Gokdag, K.; Jovanovic, B.; Kideys, A.E. Microplastic litter composition of the Turkish territorial waters of the Mediterranean Sea, and its occurrence in the gastrointestinal tract of fish. Environmental Pollution 2017, 223, 286-294, http://dx.doi.org/10.1016/j.envpol.2017.01.025.

60. McCormick, A.; Hoellein, T.J.; Mason, S.A.; Schluep, J.; Kelly, J.J. Microplastic is an abundant and distinct microbial habitat in an urban river. Environmental Science Technology 2014, 48, 11863-11871, http://dx.doi.org/10.1021/es503610r.

61. Song, Y.K.; Hong, S.H.; Jang, M.; Han, G.M.; Rani, M.; Lee, J.; Shim, W.J. A comparison of microscopic and spectroscopic identification methods for analysis of microplastics in environmental samples. Marine Pollution Bulletin 2015, 93, 202-209, http://dx.doi.org/10.1016/j.marpolbul.2015.01.015.

62. Lima, A.R.; Costa, M.F.; Barletta, M. Distribution patterns of microplastics within the plankton of a tropical estuary. Environmental Research 2014, 132, 146-155, http://dx.doi.org/10.1016/j.envres.2014.03.031.

63. Desforges, J.P.; Galbraith, M.; Dangerfield, N.; Ross, P.S. Widespread distribution of microplastics in subsurface seawater in the NE Pacific Ocean. Marine Pollution Bulletin 2014, 79, 94-99, http://dx.doi.org/10.1016/j.marpolbul.2013.12.035.

64. Lusher, A.L.; Burke, A.; 'O'Connor, I.; Officer, R. Microplastic pollution in the Northeast Atlantic Ocean: validated and opportunistic sampling. Marine Pollution Bulletin 2014, 88, 325-333, http://dx.doi.org/10.1016/j.marpolbul.2014.08.023.

65. Cole, M.; Webb, H.; Lindeque, P.; Fileman, E.S.; Halsband, C.; Galloway, T.S. Isolation of microplastics in biota-rich seawater samples and marine organisms. Scientific Reports 2014, 4, 1-8, https://doi.org/10.1038/srep04528.

66. Masura, J.; Baker, J.; Foster, G.; Arthur, C. Laboratory methods for the analysis of microplastics in the marine environment: Recommendations for quantifying synthetic particles in waters and sediments. NOAA technical memorandum NOS-OR\&R 36, 2015.

67. Dubiash, F.; Liebezeit, G. Suspended microplastics and black carbon particles in the jade system, Southern North Sea. Water, Air and Soil Pollution 2013, 224, https://doi.org/10.1007/s11270-012-1352-9. 
68. Brandon, J.; Goldstein, M.; Ohman, M.D. Long-term aging and degradation of microplastic particles: comparing in situ oceanic and experimental weathering patterns. Marine Pollution Bulletin 2016, 110, 299308, http://dx.doi.org/10.1016/j.marpolbul.2016.06.048.

69. Cincinelli, A.; Scopetani, C.; Chelazzi., D.; Lombardini, E.; Martellini, T.; Katsoyiannis, A.; Fossi, M.C.; Corsolini, S. Microplastic in the surface waters of the Ross Sea (Antarctica): Occurrence, distribution and characterization by FTIR. Chemosphere 2017, 175, 391-400, https://doi.org/10.1016/j.chemosphere.2017.02.024.

70. Maes, T.; Jessop, R.; Wellner, N.; Haupt, K.; Mayes, A.G. A rapid-screening approach to detect and quantify microplastics based on fluorescent tagging with Nile red. Scientific Reports 2017, 7, http://dx.doi.org/10.1038/srep44501.

71. Frias, J.P.; Sobral, P.; Ferreira, A.M. Organic pollutants in microplastics from two beaches of the Portuguese coast. Marine Pollution Bulletin 2010, 60, 1988-1992, http://dx.doi.org/10.1016/j.marpolbul.2010.07.030.

72. Majewsky, M.; Bitter, H.; Eiche, E.; Horn, H. Determination of microplastic polyethylene (PE) and polypropylene (PP) in environmental samples using thermal analysis (TGA-DSC). Science of the Total Environment 2016, 568, 507-511, https://doi.org/10.1016/j.scitotenv.2016.06.017.

73. Claessens, M.; Meester, S.D.; Landuyt, L.V.; Clerck, K.D.; Janssen, C.R. Occurrence and distribution of microplastics in marine sediments along the Belgian coast. Marine Pollution Bulletin 2011, 62, 2199-2204, https://doi.org/10.1016/j.marpolbul.2011.06.030.

74. Besley, A.; Vijver, M.G.; Behrens, P.; Bosker, T. A standardized method for sampling and extraction methods for quantifying microplastics in beach sand. Marine Pollution Bulletin 2017, 114, 77-83, http://dx.doi.org/10.1016/j.marpolbul.2016.08.055.

75. Wessel, C. C.; Lockridge, G. R.; Battiste, D.; Cebrian, J. Abundance and characteristics of microplastics in beach sediments: insights into microplastic accumulation in northern Gulf of Mexico estuaries. Marine Pollution Bulletin 2016, 109, 178-183, http://dx.doi.org/10.1016/j.marpolbul.2016.06.002.

76. Browne, M.A.; Galloway, T.; Thompson, R. Spatial patterns of plastic debris along estuarine shorelines. Environmental Science \& Technology 2010, 44, 3404-3409, http://dx.doi.org/10.1021/es903784e.

77. Van Cauwenberghe, L.; Vanreusel, A.; Mees, J.; Janssen, C.R. Microplastic pollution in deep-sea sediments. Environmental Pollution 2013, 182, 495-499, http://dx.doi.org/10.1016/j.envpol.2013.08.013.

78. Crichton, E.M.; Noel, M.; Gies, E.A.; Ross, P.S. A novel, density-independent and FTIR-compatible approach for the rapid extraction of microplastics from aquatic sediments. Analytical Methods 2017, 9, 1419-1428, http://dx.doi.org/10.1039/c6ay02733d.

79. Wong, J.K.H.; Lee, K.K.; Tang, D.K.H.; Yap, P.S. Microplastics in the freshwater and terrestrial environments: Prevalence, fates, impacts and sustainable solutions. Science of the Total Environment 2020, 719, https://doi.org/10.1016/j.scitotenv.2020.137512.

80. Wright, S.L.; Thompson, R.C.; Galloway, T.S. The physical impacts of microplastics on marine organisms: a review. Environmental Pollution 2013, 178, 483-492, https://doi.org/10.1016/j.envpol.2013.02.031.

81. Omidi, A.; Naeemipoor, H.; Hosseini, M. Plastic debris in the digestive tract of sheep and goats: An increasing environmental contamination in Birjand, Iran. Bulletin of Environmental Contamination and Toxicology 2012, 88, 691-694, https://doi.org/10.1007/s00128-012-0587-x.

82. Lwanga, E.H.; Vega, J.M.; Quej, V.K.; Chi, J.D.L.A.; Cid, L.S.D.; Segura, G.E.; Gertsen, H.; Salanki, T.; Ploeg, M.V.D.; Koelmans, A.A.; Geissen, V. Field evidence for transfer of plastic debris along a terrestrial food chain. Scientific Reports 2017, 7, https://doi.org/10.1038/s41598-017-14588-2.

83. Connors, K.A.; Dyer, S.D.; Belanger, S.E. Advancing the quality of environmental microplastic research. Environmental Toxicology and Chemistry 2017, 36, 1697-1307, https://doi.org/10.1002/etc.3829.

84. Lambert, S.; Scherer, C.; Wagner, M. Ecotoxicity testing of microplastics: considering the heterogeneity of physicochemical properties. Integrated Environmental Assessment and Management 2017, 13, 470-475.

85. Fuller, S; Gautam, A. A procedure for measuring microplastics using pressurized fluid extraction. Environmental Science and Technology 2016, 50, 5774-5780, https://doi.org/10.1021/acs.est.6b00816.

86. Maab, S.; Daphi, D.; Lehmann, A.; Rillig, M.C. Transport of microplastics by two collembolan species. Environmental Pollution 2017, 225, 456-459, https://doi.org/10.1016/j.envpol.2017.03.009.

87. Zhu, B.K.; Fang, Y.M.; Zhu, D.; Christie, P.; Ke, X.; Zhu, Y.G. Exposure to nanoplastics disturbs the gut microbiome in the soil oligochaete Enchytraeus crypticus. Environmental Pollution 2018, 239, 408-419, https://doi.org/10.1016/j.envpol.2018.04.017. 